\title{
A teologia de Jürgen Moltmann e a psicanálise de Freud
}

\author{
The theology of Jürgen Moltmann and the \\ psychoanalysis of Freud
}

\section{La teologia de Jürgen Moltmann y la psicoanálisis de Freud}

\author{
Fernando Cardoso Bertoldo
}

\begin{abstract}
RESUMO
O presente artigo parte do princípio que o sofrimento divino é, para Moltmann, reconhecer a humanidade de Deus - pré-requisito para uma compreensão madura da religião. Assim, as pessoas que permanecem apegadas a rituais obsessivos, que obedecem a uma religiosidade caricatural, são as que não atingiram a maturidade necessária para discernir entre o que é saudável e o que é neurótico, não entendendo Deus em sua totalidade. Abandonar essa religiosidade caricatural, assim como as ilusões e obsessões, é o único caminho possível para que o ser humano encontre a plenitude. À medida que o indivíduo amadurece e consegue superar suas conflituosas relações de ordem edipiana, indo ao encontro de sua maturidade psicológica, ele se descobre capaz de vencer a onipotência (imatura, presumida) para encontrar-se com sua própria finitude, reconciliando-se com Deus. Assim, apesar das grandes diferenças entre a teologia e a psicanálise, acreditamos que existam entre elas convergências importantes, e que uma colaboração mútua se faz necessária.

Palavras-chave: Sigmund Freud; Jürgen Moltmann; neurose obsessiva; religião.
\end{abstract}

\begin{abstract}
The present paper assumes that the divine suffering is, for Moltmann, to recognize the humanity of God - prerequisite for a mature understanding of religion. Thus, people who remain attached to obsessive rituals, obeying a caricatured religiosity, are those who have not reached the maturity necessary to discern between what is healthy and what is neurotic, not understanding God in its totality. To abandon this caricatured religiosity, as well as the illusions and obsessions, is the only possible way for the human being to find the fullness. As the individual matures and is able to overcome his conflicting oedipal relationships, meeting his psychological maturity, he finds himself able to overcome omnipotence (immature, presumed) to meet his own finitude, reconciling himself with God. Thus, in spite of the great differences between theology and psychoanalysis, we believe that there are important convergences among them, and that mutual collaboration is necessary.
\end{abstract}

Keywords: Sigmund Freud; Jürgen Moltmann; obsessive neurosis; religion.

\section{RESUMEN}

El presente artículo parte del principio de que el sufrimiento divino es, para Moltmann, reconocer a la humanidad de Dios - prerrequisito para una comprensión madura de la religión. Así, las personas que permanecen apegadas a rituales obsesivos, que obedecen a una religiosidad caricatural, son las que no alcanzaron la madurez necesaria para discernir entre lo que es saludable y lo que es neurótico, no entendiendo a Dios en su totalidad. Abandonar esa religiosidad caricatural, así como las ilusiones y obsesiones, es el único camino posible para que el ser humano encuentre la plenitud. A medida que el individuo madura y logra superar sus conflictivas relaciones de orden edípico, yendo al encuentro de su madurez psicológica, 
se descubre capaz de vencer la omnipotencia (inmadura, presumida) para encontrarse con su propia finitud, reconciliándose con Dios. Así, a pesar de las grandes diferencias entre la teología y el psicoanálisis, creemos que existen entre ellas convergencias importantes, y que una colaboración mutua se hace necesaria.

Palabras clave: Sigmund Freud; Jürgen Moltmann; neurosis obsessiva; religión.

\section{Introdução}

Jürgen Moltmann produziu uma vasta obra teológica, carregada de aspectos autobiográficos, que vão desde sua juventude, quando foi recrutado pelo exército alemão para lutar na Segunda Guerra, até as consequências de sua prisão na Inglaterra. Moltmann descreve o impacto que esses fatos tiveram em sua obra, refletindo também sobre o que ele entende como o esvaziamento de sentido da sociedade contemporânea. Esses aspectos podem ser vistos nas obras "Teologia da Esperança" (1964), "O Deus crucificado" (1972) e "Trindade e Reino de Deus" (1986), dentre outras.

Freud tem uma vasta obra composta por textos, artigos e livros. Seus grandes clássicos são "A Interpretação dos sonhos" (1899), "Três ensaios sobre a teoria da sexualidade" (1905), "Totem e tabu" (1913), "O futuro de uma ilusão" (1927), "O ego e o id" (1923), "Mal-estar na civilização" (1929) e "Moisés e o monoteísmo" (1939), dentre outras obras.

Rotular a psicanálise como uma ciência judaica, tendo em vista a ascendência do autor, implicaria para Freud aceitar certas companhias não muito agradáveis. Assim, "os partidários dessa noção constituíam uma aliança incongruente que abarca judeus ávidos por se apossar de Freud e gentios ansiosos e rancorosos por desacreditá-lo" (GAY, 2012, p.650). Esses aspectos são centrais quando se discute a formação da psicanálise e seu status científico.

Moltmann é um dos teólogos mais respeitados e influentes do mundo contemporâneo. Seu trabalho teológico é muito expressivo. Ele é uma das figuras mais representativas da teologia protestante contemporânea, depois de grandes líderes anteriores como Barth, Cullmann, Tillich e Bonhoeffer (MONDIN, 2003, p.28). Moltmann é de confissão cristã reformada, nascido em 18 de abril de 1926, na cidade de Hamburgo, Alemanha (KUZMA, 2009, p.446). Aos dezessete anos, após ver a sua cidade destruída em julho de 1943, foi convocado para o front alemão como soldado recém-incorporado. Depois de seis meses em guerra, foi feito prisioneiro e levado ao campo de prisioneiros $^{1}$ de Northon Camp (KUZMA, 2009,p.446). Essas experiências foram extremamente dolorosas para Moltmann, causando-lhe muito sofrimento e lhe sugerindo que a condição humana é marcada pela ausência de perspectivas, mas repleta de desesperança. Em seus relatos autobiográficos, Moltmann escreve que

\footnotetext{
1 Nas traduções brasileiras feitas das obras de Moltmann, sempre se traduz que ele esteve preso em campo de concentração, mas, na verdade, a tradução correta seria campo de prisioneiros.
} 
Qualquer pessoa que teve de gritar a Deus face à mutilação e morte de tantas outras que tinham sido companheiras, amigas e parentes, não mais poderá fazer uma abordagem reservada e individual da teologia. O problema é: como se pode falar de Deus "depois de Auschwitz". Mas, mais ainda: como se pode não falar de Deus depois de Auschwitz (MOLTMANN, 2005, p. 13).

Tais experiências não levaram Moltmann à amargura e à descrença de sentido na existência humana. Elas o conduziram a repensar o sentido da esperança em uma sociedade que, para ele, simplesmente havia se perdido em meio ao caos. Assim, essas experiências o levaram a desenvolver uma concepção teológica que tenta dar conta das necessidades do mundo contemporâneo, levando em consideração os elementos conflituosos que estão conduzindo a humanidade a uma suposta crise global que, para ele, expande-se em todos os sentidos: ecológico, econômico, social, etc.

Diante desses questionamentos, Moltmann começou a se perguntar o que conduziu a sociedade a essa crise de sentido. Logo, o tema da esperança passou a ocupar uma posição central em sua obra. Ele realizou uma releitura do pensamento do filósofo marxista Ernst Bloch, autor que buscou através da esperança humanizar o marxismo e libertar os homens da alienação. Uma obra de Bloch que causou grande impacto em sua teologia foi "O princípio esperança” (1954-1959). Ela levou Moltmann a se questionar sobre o papel da esperança para a teologia, perguntando-se o que teria restado da esperança do cristianismo primitivo nos dias atuais - questionamento que o autor aborda com maestria na obra "Teologia da esperança".

Para Moltmann, a esperança é uma questão fundamental nos dias de hoje. Ele acredita que no fim de tudo está Deus. A história, interpretada como promessa redentora, pode ser lida como uma manifestação de Deus enquanto futuro por vir. Assim, a finalidade da existência humana é, para Moltmann, a espera na Parúsia ${ }^{2}$, pois "no fim estará a nova criação de Deus (Lc 21, 28; Ap 21, 1), prometida e confirmada na história de Jesus Cristo" (MOLTMANN, 2002, p. 130-140). Através da esperança, a Parúsia libertaria a humanidade de todo sofrimento.

A esperança só seria possível, segundo Moltmann, através da maturidade cristã, estado de espírito capaz de desviar o ser humano das ilusões e das desesperanças do mundo. Estar em paz com Deus, consequentemente, seria estar em desarmonia com o mundo. "A verdadeira esperança perscruta além dos horizontes apocalípticos de nosso mundo moderno, vendo a nova criação de todas as coisas no reino da glória de Deus" (MOLTMANN, 2004, p. 47).

2 Parúsia: segunda vinda de Jesus Cristo. 
Se a esperança não trouxer essa inquietude e esse anseio pelo reino vindouro, não passará de uma falsa esperança, segundo a definição de Moltmann, e frustrará o ser humano já em seu presente. O indivíduo torna-se, nessa perspectiva, um prisioneiro do passado, sem qualquer projeção de futuro (KUZMA, 2009, p. 457). Moltmann acredita que a verdadeira esperança traz à tona um motivo pelo qual viver em uma contemporaneidade destituída de sentido:

\footnotetext{
Moltmann nos insere dentro do contexto de sua obra. Como ele mesmo diz, ele não é apenas o único autor, mas como todos os leitores, ele foi influenciado por ela [sua própria obra]. Em algumas vezes, durante os anos que se seguiram pós-obra, ele mudou de posturas em relação à esperança, fato que ocorreu pelo retorno que sua obra lhe trouxe quando entrou em contato com outros horizontes e com outras visões hodiernas da teologia (KUZMA, 2009, p. 447).
}

A evolução da cristologia de Moltmann acaba culminando em uma visão do Deus Trino que sofre - não como uma divindade imóvel e impassível, mas em uma dinâmica de real relação entre o Pai e o Filho, cuja cruz é a base da argumentação teológica cristã (ALBUQUERQUE; CORTES, 2012. p.4). Essa capacidade divina de sofrer implicaria na quebra do estereótipo teológico em que Deus é apático ao sofrimento humano, contrariando, assim, a "guinada antropológica" que retrata a ordem cosmológica focando-se somente na humanidade, sem nenhum traço de divindade. De acordo com Moltmann, o homem que atinge a maturidade cristã torna-se a medida de si mesmo e um espelho da própria divindade (ALBUQUERQUE; CORTES, 2012. p.27). Deus se torna prova subjetiva, necessária para conferir consistência à subjetividade humana. Dessa forma, a prova cosmológico-objetiva seria substituída por uma existencial-subjetiva (MOLTMANN, 2000. p.28).

Com base nas explanações que fizemos sobre a esperança, acrescentamos que a teologia de Moltmann constitui-se de estudos tanto filosóficos quanto bíblicos. O autor trabalha, em "Teologia da Esperança", os conceitos de esperança apocalíptica, teologia do apostolado, teologia bíblica da promessa e também a filosofia da esperança de Ernst Bloch.

Com essa breve explanação sobre a vida e a obra de Moltmann, trataremos a seguir da difícil relação entre a psicanálise e a teologia, buscando demonstrar que é possível desenvolver um diálogo profícuo entre ambas as partes, tendo em vista que a teologia da esperança em Moltmann caracteriza-se pela busca da salvação em um futuro por vir, o que implicaria na necessidade de uma libertação psíquica nos moldes freudianos. Tendo isso em vista, apresentaremos as possiblidades de diálogo como também as possíveis contribuições da psicanálise à teologia, dentro da perspectiva de Moltmann. Para o autor, a esperança só pode mudar a vida humana se a relação entre 
Deus e a humanidade for repensada, e se o ser humano se libertar de suas ilusões relacionadas a Deus, tais como projeções de ídolos e outras distorções.

\section{A psicanálise de Freud e a "Teologia da Esperança" de Jürgen Moltmann: interseções (im)possíveis?}

Freud, ao longo de sua trajetória como médico e criador da psicanálise, visou conduzir a humanidade à libertação de suas ilusões, ajudando-a a lidar com suas frustações e a alcançar a maturidade psíquica que a libertaria da necessidade de Deus. Como vimos, a religião, para ele, seria apenas uma outra forma de ilusão que atuava como obstáculo para a saúde psíquica humana, provocando uma espécie de atrofia mental. Em "O futuro de uma ilusão" (1927), Freud conjectura que a ciência viria a tomar o lugar da religião e que, consequentemente, os homens aprenderiam a lidar com suas frustrações sem recorrer a ídolos tais como deuses - de acordo com ele, projeções da figura paterna. Como se pode notar em "O futuro de uma ilusão", Freud tece suas mais severas críticas à religião:

\footnotetext{
Basta-nos que as tenhamos reconhecido como sendo, em sua natureza psicológica, ilusões. Contudo, não somos obrigados a ocultar o fato de que essa descoberta também influencia fortemente nossa atitude para com a questão que a muitos deve parecer a mais importante de todas. Sabemos aproximadamente em que períodos, e por que tipo de homens, as doutrinas religiosas foram criadas. Se, ademais, descobrirmos os motivos que conduziram a isso, nossa atitude para com o problema da religião experimentará um acentuado deslocamento. E seria ainda mais notável se nossos lamentáveis, ignorantes e espezinhados ancestrais tivessem conseguido solucionar todos esses difíceis enigmas do universo (FREUD, 1996, p. 42-43).
}

Freud não só buscou explicar a origem da religião e da religiosidade nesta obra, como também pressupôs um processo de definhamento da religião ${ }^{3}$ a partir do desenvolvimento e dos avanços da ciência moderna. Zeferino Rocha defende que, em "O futuro de uma ilusão", "a razão impera como em um reinado soberano, e as produções humanas devem todas ser submetidas ao seu poderoso tribunal, principalmente a suposta verdade das ideias religiosas" (ROCHA; MACIEL, 2008. p.737). E apesar dessa defesa à razão, o próprio Freud admite que

o desamparo do homem, porém, permanece e, junto com ele, seu anseio pelo pai e pelos deuses, reconciliar os homens com a crueldade do Destino, particularmente a que é demonstrada na morte, e compensá-los pelos sofrimentos e privações que uma vida civilizada em comum lhes impôs (FREUD, 1996, p. 27-28).

\footnotetext{
A relação de Freud com a religião sempre foi conflituosa. Mas também se faz necessário ressaltar que Freud ficava divido com relação ao misticismo, questão que pode ser vista nas cartas entre Freud e Romain Rolland, nas quais Freud não dizia necessariamente que era contra o misticismo, e sim, que não o compreendia em sua totalidade. Então, a crítica de Freud ao misticismo teria um cunho científico baseado na ciência moderna, mas não necessariamente que ele rejeitasse o misticismo em sua totalidade.
} 
Para Moltmann, a crucificação de Cristo representa o abandono de Deus ao sofrimento humano, e a compreensão desse abandono conduziria os indivíduos a se libertarem das distorções religiosas, tendo em vista essa solidariedade de Deus com a dor humana. Essa perspectiva seria o fundamento da maturidade cristã, de acordo com Moltmann, que acredita serem a crucificação e a ressurreição fundamentos sólidos para a busca de sentido tanto na história quanto na própria vida.

Ainda segundo Moltmann, o futuro de Deus é a origem criadora de todas as coisas na contingência da sua existência, e é, ao mesmo tempo, o último horizonte para o significado definitivo; é, portanto, a essência de todas as coisas e acontecimentos (PANNENBERG, 2009, p. 698). Para o autor, "Reino de Deus significa originariamente reino em promessa, fidelidade e cumprimentos. A vida neste reino significa, portanto, peregrinação histórica, movimento e obediente prontidão frente ao futuro"(MOLTMANN, 2005, p. 273).

Segundo Moltmann, “à medida que o homem desenvolve o seu parâmetro de vida, com relação à divindade do seu Deus, devemos nos perguntar: quem é o homem perante o Filho rejeitado, que ressuscitou na liberdade de Deus?" (MOLTMANN, 2011, p.355). Assim, o Deus crucificado é um Deus humanizado, que sofre com o ser humano e não é apático ao seu sofrimento. Tendo isso em vista, as enfermidades de um mundo caótico como o nosso não implicariam que Deus tenha abandonado o ser humano, e sim que ele se abandonou no sofrimento dos homens. Segundo Moltmann,

[...] se tentarmos sustentar as consequências da teologia do Deus crucificado para a antropologia, não poderemos permanecer dentro do monólogo da antropologia teológica, mas teremos que entrar em diálogo com outras imagens do homem. Se tentarmos traçar a libertação do homem, o primeiro passo é inevitavelmente um diálogo com a ciência antropológica, que se preocupa com a terapia do homem enfermo. Acima de tudo, essa é uma questão da psicanálise de Sigmund Freud. (MOLTMANN, 2011, p. 355).

Moltmann defende, assim, que para que o indivíduo moderno se liberte de sua desesperança e da crise de sentido, faz-se necessário que a teologia dialogue com outras áreas, como a antropologia e a psicanálise.

$\mathrm{Na}$ obra de Moltmann, a fé é transpassada pela esperança, assim como a esperança é transpassada pela fé. Uma vez que as pessoas abandonem projeções, ídolos e tabus, elas conseguem encontrar o caminho da esperança, que seria a finalidade da teologia e da escatologia. Entra aqui a dimensão histórico-salvífica de Jesus, que ascende para uma compreensão escatológico-soteriológica de sua missão (SCHILLEBEECKS, 2007, p. 144). Essa compreensão escatológica e soteriológica torna-se possível na medida em que nos libertamos das amarras das ilusões e distorções religiosas. 
Essa relação entre a fé e a esperança, como vimos, só seria possível por meio da maturidade e da cura psíquica, de acordo com Moltmann. Segundo ele, "a conversa teológica com Freud realmente só começou nas últimas décadas. Uma discussão sobre a crítica da religião de Freud é, portanto, importante para teologia crítica" (MOLTMANN, 2011, p. 355). Para o autor, a esperança não pode mais ser direcionada apenas ao final, como era apresentada no passado, sendo como um apêndice da teologia. Ela deve envolver o todo, pois faz parte do todo" (KUZMA, 2009.p. 451).

Tal mudança de paradigma pode se tornar possível através da hermenêutica psicológica, pois a esperança pressupõe maturidade psicológica dentro da perspectiva antropológica: "Qualquer um que segue a Paulo, falando sobre a liberdade dos filhos de Deus na fé em Cristo, também deve buscar apresentar essa liberdade em termos psicológicos e políticos específicos" (MOLTMANN, 2011, p. 356.). Essas questões encontram eco no início da obra "Teologia da Esperança", onde Moltmann se refere à redescoberta da escatologia com base nas investigações sobre o Jesus histórico, mas relatando a não efetividade dessa descoberta. Ressaltamos, porém, o importante aspecto que a não efetividade dessa descoberta vai ter na obra de Moltmann, uma vez que ele vai encontrar a solução para o esvaziamento de sentido contemporâneo na esperança.

Observamos, assim, possibilidades de um diálogo profícuo para ambas as partes: a psicanálise não ficaria enredada em questões unicamente de ordem patológica, e a religião também passaria a dialogar com outras ciências de ordem antropológica, assim estendendo suas pesquisas para além da reflexão teológica. O que une a religião e a psicanálise é, acima de tudo, seu objetivo de libertar o ser humano e levá-lo à plena maturidade.

Foi em sua obra "Atos obsessivos e prática religiosa" (1907) que Freud atribuiu primeiramente o sentimento religioso à neurose obsessiva, caracterizando a religião como uma patologia camuflada que coibiria elementos de ordem inconsciente que, se não contidos, poderiam conduzir a humanidade à sua autodestruição. Para Freud, as pessoas que praticam "atos obsessivos ou cerimoniais pertencem à mesma classe das que sofrem de pensamento obsessivo, ideias obsessivas, impulsos obsessivos e afins" (FREUD, 1996, p.109). O fenômeno seria "uma entidade clínica especial, que comumente se denomina de "neurose obsessiva' [Zwangsneurose]" (FREUD, 1996, p.109). Ele ressalta, porém, que não se deve "inferir de tal denominação a natureza da enfermidade, pois, a rigor, também outras espécies de fenômenos mentais mórbidos podem possuir características 'obsessivas" (FREUD, 1996, p.109).

Moltmann ressalta, no entanto, que "Sigmund Freud desenvolveu a psicanálise na terapia de indivíduos doentes. Mas, com o passar do tempo, 
ele se interessou mais pelos condicionamentos sociopsicológicos e culturais das doenças" (MOLTMANN, 2011, p. 359). Assim ele identifica um dos limites da psicanálise:

\begin{abstract}
Sua análise da sociedade, com a ajuda dos padrões das doenças individuais, geralmente sobe para as nuvens de especulação e não possui mais um efeito terapêutico. Aqui está um limite para psicoterapia que deve ser observado, se uma metapsicologia não verificável pretende ser evitada: a análise demonstra a doença da sociedade pelo exemplo do homem doente, mas a terapia só pode começar com o indivíduo. Isso não a torna supérflua, já que as pessoas doentes não podem ser consoladas pela promessa de uma cura da sociedade como um todo (MOLTMANN, 2011, p. 359-360).
\end{abstract}

Por mais importante que seja a terapia em casos de pessoas enfermas, Moltmann argumenta que ela também apresenta fragilidades que podem e devem ser suprimidas através da verdade cristã. "A terapia [sic] deve estar ciente dessa limitação de sua potencialidade, na qual os círculos viciosos psicológicos estão ligados a círculos viciosos na sociedade e na política" (MOLTMANN, 2011, p. 360). Diante disso, ele busca apontar a importância da esperança como resposta para um mundo em crise. Moltmann acrescenta, ainda, que a finalidade da teologia é a escatologia. Ou seja, aquilo que esperamos no porvir integra-se na fé que nos compromete a uma missão neste mundo.

A existência cristã, por si só, apresenta críticas à religião, uma vez que a orientação escatológica do cristianismo abarca a totalidade da religião. Ou seja, ela contempla as respostas para as múltiplas críticas dirigidas ao cristianismo. Portanto,

\footnotetext{
A fé cristã pode se identificar com aquilo que Freud criticou como "religião" ou como "caricatura de religião". Nesse caso, é considerado o "pior inimigo da religião" por Marx, uma posição com a qual ocasionalmente concordava. Contudo, um cristianismo que se identifica com a religião, à medida que é atacado e criticado dessa maneira, entregou sua própria crítica da religião (MOLTMANN, 2011, p. 361).
}

Em sua abordagem sobre Freud, Moltmann busca demonstrar que mesmo a crítica psicanalítica à religião é incapaz de fugir à realidade da promessa divina, ressaltando que "o melhor curso apologético para uma tipologia religiosa equivalente seria não rejeitar Freud como um irreligioso, mas demonstrar em sua crítica da religião, as implicações religiosas que ele mesmo criticou" (MOLTMANN, 2011, p.361). E, mesmo assim, apesar da psicanálise incluir de certa forma uma atitude escatológica, de acordo com Moltmann, reiteramos que a maturidade psíquica proporcionada pelas teorias de Freud não é capaz de curar sozinha a sociedade como um todo.

Concordamos, assim, com Ratzinger, quando ele afirma que a fé "foi sempre uma decisão que envolveu toda a profundeza da existência, exigindo 
sempre uma virada do ser humano condicionada por uma decisão" (RATZINGER, 2005, p. 40). A fé seria o pilar fundamental da maturidade cristã, junto à maturidade psicológica. Portanto, encontramos pontos de convergência entre a crítica da religião em Freud e as ideias de Moltmann, uma vez que

\begin{abstract}
A crítica da religião encontra dificuldade em escapar do mover escatológico do seu conteúdo. Teólogos sentem que devem defender a religião cristã contra Freud e positivistas que querem se livrar da religião e da crítica da religião; deveriam, no entanto, reconhecer que Freud não identificou religião como neurose. Ele simplesmente viu a neurose como "uma caricatura da religião", da mesma maneira com que viu a histeria como caricatura da arte e a paranoia como a caricatura da filosofia. É, portanto, mais apropriado levar a crítica de Freud de maneira positiva, a fim de libertar a fé das caricaturas dos jogos patológicos que aparecem na superstição (MOLTMANN, 2011, p. 362).
\end{abstract}

Ao colocar a escatologia como esperança, Moltmann afirma que "ela toma seu ponto de partida em uma determinada realidade histórica e prediz o futuro da mesma, suas possibilidades futuras e sua eficácia futura" (MOLTMANN, 2011, p.30). Assim, estaremos contemplando "um Deus que olha com infinito respeito à autonomia de suas criaturas e cuja ação consiste em afirmá-las com um amor incondicional" (TORRES, 1995, p.248). As implicações a este respeito sobre a nossa autonomia não só sugerem a possibilidade do livre-arbítrio, que está associado à maturidade psicológica, como também da natureza humana de Deus. Assim, a esperança não seria algo que se adiciona à fé, ou que se anexa a ela, mas o outro lado da fé mesma, na medida em que ela se compreende como fé cristã (MOLTMANN, 2004, p. 53).

Para Moltmann, nossa fé se alimenta da esperança em Deus, que é "aquele que vem" (Ap 4,8): "nós vivemos no tempo do advento de Deus" (MOLTMANN, 2008, p. 13). De acordo com a definição cristã, a escatologia aborda Jesus e seu futuro; conhece a realidade da ressurreição de Jesus e anuncia seu futuro (MOLTMANN, 2008, p. 31-32). Mais ainda do que a fé, é a esperança cristã que está direcionada para contemplar e fruir o cumprimento da promissão de Deus. A esperança pergunta à sua própria maneira pelo entendimento do porquê e do quê da sua esperança (MOLTMANN, 2004, p. 53). A esperança nessa vinda significaria o movimento do amor de Deus ganhando espaço na vida, na morte e na ressurreição de Jesus, para a qual fomos chamados e encontramos a nossa salvação (KESSLER, 2002, p.389-390).

Portanto, a maturidade cristã nos permite uma libertação da desesperança e das ilusões relacionadas à crise de sentido que enxergamos no mundo contemporâneo. A esperança, para Moltmann, preencheria o vazio que teria tomado conta do homem contemporâneo, e através dela seria possível tornar presente o Reino de Deus. 
A ressurreição de Cristo seria, assim, uma antecipação da glória futura prometida desde os profetas, glória que já estaria consumada em Cristo, fonte de toda a esperança como uma plenitude escatológica (TORRES, 1995, p. 253-255). Pois a esperança da cristandade é uma esperança rememorada, escatológica: uma anti-história contra a morte e uma anti-imagem contra o ato violento da crucificação. A memória torna presente e assegura a esperança, e a esperança mantém o passado presente (MOLTMANN, 2004, p. 57). De acordo com Moltmann, o amor é a práxis do reino vindouro de Deus e de sua justiça neste mundo. Por isso, Deus estaria apaixonado criativamente pela vida

Assim, a consequência desse movimento de Deus em direção à humanidade e a toda a criação, compreendido por nós neste trabalho como o futuro de Deus, pode ser visualizada de forma concreta a partir do conteúdo do Reino de Deus. Reino que, segundo E. Schillebeeckx, vem a ser Deus (SCHILLEBEECKX, 2007, p. 150).

As promissões de Deus, porém, não devem ser concebidas "historicamente apenas porque sucederam na história e necessitam ser interpretadas de maneira sempre nova na história, mas também porque inauguram uma determinada história" (MOLTMANN, 2004, p. 90). Moltmann diria que os cristãos que seguem a missão de Cristo seguem igualmente a Cristo no serviço do mundo (MOLTMANN, 2005, p. 407). Sua mensagem sobre o Reino de Deus, de acordo com o testemunho da tradição sinótica, estava presente no centro de sua vida.

\section{Da ilusão religiosa psicanalítica à maturidade da religião no Deus crucificado}

Nessa seção, pretendemos abordar a crítica de Moltmann às seguintes obras de Freud sobre religião: “Atos obsessivos e prática religiosa" (1907), "Totem e tabu" (1913), "O futuro de uma ilusão" (1927) e "O mal-estar na civilização" (1929). Foi por volta de 1907 que Freud parece ter começado a relacionar as ações obsessivas nos neuróticos aos rituais religiosos (MOLTMANN, 2011, p. 365).

As questões relacionadas às obsessões na religião vão assumir uma substancial importância na obra de Moltmann, que escreve, em concordância com Freud: "o paciente neurótico é inclinado a se submeter a rituais particulares, a fim de se desvencilhar da dor, da pressão ou da ansiedade" (MOLTMANN, 2011, p. 365).

Esse comportamento, para Moltmann, seria uma espécie de desvio da religião. Moltmann afirma que os povos antigos, notadamente os gregos, exerceram uma influência decisiva na formação do conceito de apatia divina, viés muito similar à leitura psicanalítica da religião. 
Ao contrário da caricatura religiosa proposta pela psicanálise, na visão de Moltmann, acreditamos que o envolvimento de Deus na Paixão de Cristo não foi um ato de abandono. Acreditamos que Deus abandonou-se em seu sofrimento. Portanto, se Cristo sofreu, seu Pai também sofreu e sofre (MOLTMANN, 1993. p. 236-247.) O que implicaria, para Moltmann, em uma severa crítica à ausência de sentido na religião, conforme a proposta por Freud.

Para a psicanálise, a morte simbólica da figura paterna acarreta o desenvolvimento do chamado "animal totêmico", uma espécie de figura mítica protetora, um substituto para o papel do pai. Freud salienta a ambivalência da relação pai-filho, visto que o indivíduo deseja secretamente a morte de seu pai; e, no entanto, sua presença psicológica é sempre requisitada pela mente humana. Esses fatores teriam tido "uma influência determinante sobre a natureza da religião. A religião totêmica surgiu do sentimento filial de culpa, num esforço para mitigar esse sentimento e apaziguar o pai por uma obediência a ele que fora adiada (FREUD, 1996, p. 152-153)". Esse sentimento de culpa, para Freud, provém do desejo do indivíduo e de seus irmãos de assassinar o pai a fim de desfrutar dos privilégios do pai, podendo, assim, cometer atos incestuosos e tornarem-se chefes no clã. Devido à falta de estrutura que os irmãos demonstram para assumir o controle do clã, após assassinar o pai, eles são tomados pela culpa, desenvolvendo um sentimento de solidariedade em função do desamparo. Consequentemente, nasce uma idolatria por esse deus-pai, que remonta à morte do pai verdadeiro. Todas "as religiões posteriores [ao totemismo, a religião primeira] são vistas como tentativas de solucionar o mesmo problema" (FREUD, 1996, p. 153).

Destaquemos, aqui, algumas críticas de Moltmann em relação à perspectiva dos gregos sobre a apatia de Deus, uma vez que a filosofia grega teve um grande impacto na formulação da teologia ocidental, principalmente na conceptualização da divindade - e também na formulação da teoria psicanalítica de Freud. Moltmann afirma que os gregos acreditavam que a substância divina deveria ser apática e, portanto, autossuficiente, enquanto substância absoluta. Também concordamos com Moltmann quando ele afirma que a mensagem apresentada por Cristo se revela de outras formas que não enquanto apatia divina. Em sua vida de constante entrega e serviço, ele pôde ser identificado como "Ebed Iabweh"( CULMANN, 2004., p. 86-112), o Servo de Deus, e sua entrega diante do ato da crucificação, na morte de cruz, demonstrou sua relação de Pai e Filho, com a qual foi Filho de Deus.

Moltmann identifica, ainda, possíveis contraposições nas críticas freudianas, argumentando que "ele observou que o desaparecimento de uma religião pública, de caráter geralmente impositivo, contribuiu para o aumento 
no número de neuróticos e da caricatura da religião privada" (MOLTMANN, 2011, p.366). A redução da religião, assim, não implicaria necessariamente na diminuição das neuroses.

No âmbito social, Moltmann argumenta que ações de religiões públicas possuem uma importância simbólica. Somente quando aqueles que creem na religião pública deixam de se perguntar pela importância dessas ações e de seus símbolos religiosos, não mais os compreendendo, é que os fardos se tornam alienações. Somente nesse caso, para Moltmann, os símbolos se tornariam ídolos e os rituais se converteriam em ações obsessivas. Com a alienação dos significados, a religião assumiria de fato as características de uma neurose compulsiva universal. Ela se tornaria, como mencionamos, uma caricatura de si mesma, produzindo indivíduos doentes. A declaração freudiana de que "a religião é uma neurose obsessiva universal" seria verdadeira nesse caso. "Ainda assim, essa fé com suas consequências é adequada para libertar as pessoas de suas ilusões culturais, soltá-las dos seus contextos ofuscantes e confrontá-las com a verdade de sua existência e sua sociedade." (MOLTMANN, 2011, p. 48-49).

As pessoas que permanecem apegadas a rituais obsessivos, como vimos, não atingiram a maturidade necessária para discernir entre a religiosidade saudável e a religião infantilizada. Moltmann destaca, porém, que o desenvolvimento psíquico rumo à maturidade e em afastamento à infantilidade é um processo que nunca se completa: "devido às experiências da infância opressiva - e, porque o processo de amadurecimento nunca pode ser visto como algo completo, no fim, isso se refere a todos os homens - sempre faz para si ídolos e valores que, para ele, se tornam idênticos a si mesmo, pois faz com que a existência dependa deles" (MOLTMANN, 2011, p. 370).

Moltmann assume, como Freud, que questões referentes ao princípio do prazer são uma fonte de alienação para os indivíduos, não permitindo que atinjam uma maturidade psicológica e mantendo-os presos a vivências infantis.

Os homens continuam dependentes do princípio do prazer e enraizados no predomínio de suas vontades, ou amadurecem e aceitam o princípio da realidade e entram em acordo com a realidade. O caminho para a maturidade é o caminho do prazer em direção ao princípio da realidade (MOLTMANN, 2011, p. 378).

Como solução proposta por Moltmann, a maturidade deve passar pela compreensão do amor divino. Para ele, Deus é amor e, enquanto amor, ele não é um Deus insensível ao sofrimento humano, como já vimos. Enquanto amor, ele se adapta à sua criação e se entrega totalmente. A onipotência divina, assim, não seria uma onipotência enquanto insensibilidade e sim quanto à passividade, revelada na entrega de Cristo diante da crucificação (KITA- 
MORI, 1975, p. 199-206) - que, como já destacamos, concede o significado mesmo de ser cristão.

O conceito de parricídio, como vimos, exerce um papel basilar na psicanálise. Em "Totem e tabu" (1913), Freud defende que "a interpretação da ansiedade pela culpa, por meio da história de Édipo, essencialmente faz com que o parricídio seja a lei de acordo com a qual nós avançamos" (MOLTMANN, 2011, p. 375-376).

Freud presume, assim, que o desenvolvimento das religiões se deve ao sentimento de culpa do filho devido à sua rebeldia. As tentativas feitas para “[...] solucionar os problemas religiosos, os tipos de reconciliação efetuados entre essas duas forças mentais opostas, mais cedo ou mais tarde, ruíam sob a influência combinada, sem dúvida, dos fatos históricos, das mudanças culturais e das modificações psíquicas internas" (FREUD, 1996, p. 159).

Em suas especulações, Freud escreve em "O futuro de uma ilusão" (1929) que se fica "assim com a impressão de que a civilização é algo que foi imposto a uma maioria resistente por uma minoria que compreendeu como obter a posse dos meios de poder e coerção" (FREUD, 1996, 159). No entanto, ele não acredita que esse tipo de estrutura exploratória seja inerente à natureza da própria civilização; para ele, essas dificuldades são "determinadas pelas imperfeições das formas culturais que até agora se desenvolveram" (FREUD, 1996, p. 16).

Para Moltmann, no entanto, "a fé cristã não se encontra na situação de uma autoridade paterna divina e tirânica, que é desejada como uma função divina e protetora e odiada como um privilégio divino" (MOLTMANN, 2011, p. 376). Acreditamos, assim, que se tornam plausíveis as críticas de Moltmann, para quem "[...] a fé cristã deve primeiro purificar suas igrejas dos ídolos e tabus, das concepções de autoridade e expiação, cujas estruturas edipiais Freud analisou de maneira adequada" (MOLTMANN, 2011, p. 376).

Ainda com relação às ilusões, Moltmann defende que "uma esperança que foi consolidada como ilusão não precisa, necessariamente, contradizer a realidade. A sua única característica é a sua base dos desejos humanos. Onde quer que fale sobre salvação, a religião, na verdade, tem a ver com os desejos e esperanças humanas fundamentais” (MOLTMANN, 2011, p. 380).

As ilusões infantilizadas não seriam, assim, prejudiciais ao ser humano em toda e qualquer situação, mas apenas quando configuradas de maneira patológica. "Há situações da humanidade doente e reprimida, e o elemento da doença e da opressão é expresso nessas formações de padrões específicos, que pretendem proteger a vida das enfermidades e opressões" (GIBELLINI, 1975. p. 385). Acreditamos que uma das saídas para essas ilusões e distorções 
possa ser a aceitação das pessoas em carregar sua própria cruz, da mesma forma Cristo aceitou a crucificação; em outras palavras, a solução seria aceitar os desafios e dificuldades que o mundo contemporâneo nos traz, mas não nos corrompendo com as situações cotidianas, uma vez que estar em harmonia com Deus é estar em desarmonia com o mundo.

\section{Considerações finais}

Assim concluímos o artigo, na esperança de ter demonstrado que é possível encontrar elementos construtivos para a teologia na obra de Freud, e que o debate teológico entre psicologia e teologia pode ser frutífero para ambas as partes. Uma teologia que defende o sofrimento divino e a humanidade de Deus precisa encontrar soluções em conjunto com as ciências, se quiser encontrar soluções para a crise de sentido e de esperança que acreditamos assolar a contemporaneidade. Acreditamos que não há mais espaço para uma teologia que se isente de reflexões de cunho psicológico, e também acreditamos que a psicanálise não deve ignorar a doutrina cristã ao buscar a cura psíquica de enfermos. As contribuições mútuas, em nossa opinião, são possíveis e necessárias para ambas as partes, uma vez que elas tenham como objetivo a cura e a libertação dos homens através da relação entre a fé, a esperança e a libertação psicológica, que são indissociáveis entre si.

Como teoriza Moltmann, é imprescindível conhecer o envolvimento de Deus no sofrimento de Jesus Cristo para compreender a relação entre a maturidade cristã e o sofrimento divino. Pois, como vimos, é justamente o sofrimento de Cristo que dá sentido à existência humana. Essa perspectiva, inclusive, cria uma convergência entre a teologia de Moltmann e a psicanálise: se Freud defendia que o ser humano precisa se libertar das ilusões e perceber que está sozinho e desamparado, e que esse sentimento de abandono constituiria sua maturidade, destacamos que é precisamente esse mesmo sentimento de abandono e maturidade que Moltmann identifica como sendo o sentido da fé cristã. Assumimos, assim, que a maturidade cristã vem a ser a renúncia dos ídolos e das distorções religiosas, ou seja, a renúncia à nossa pretensa onipotência, aceitando nossa finitude para nos reconciliarmos com Deus.

Tendo em vista a teologia de Moltmann, podemos levantar ainda algumas questões sobre as naturezas humana e divina de Deus, questionando até que ponto Deus pode sofrer sem perder sua natureza divina, e até que ponto ele pode amar a humanidade sem deixar de ser divino. Essa ideia de sofrimento divino proposta por Moltmann quebra o estereótipo da apatia de Deus frente ao sofrimento humano, o que vem tornando esse debate cada vez mais interessante e profundo. 


\section{Referências bibliográficas}

ALBUQUERQUE, B. S.; CORTES, R. J. M. Espírito Santo: caminho da liberdade. Elementos de pneumatologia da libertação em Basílio, Gutiérrez, Boff e Codina. Pós-Escrito, Rio de Janeiro, v. 6, p. 3-20, 2012.

BÍBLIA. Português. A Bíblia de Jerusalém. Nova edição rev. e ampl. São Paulo: Paulus, 2002.

CULMANN, O. Cristologia do Novo Testamento. São Paulo: Custom, 2004.

FREUD, S. Além do princípio do prazer, psicologia de grupo e outros trabalhos (1920-1922). Rio de Janeiro: Imago, 1996.

GAY, P. Freud: uma vida para o nosso tempo. São Paulo: Companhia das Letras, 2012.

GIBELLINI, R. La teología di Jürgen Moltmann. Brescia: Queriniana, 1975.

KESSLER, H. Cristologia. In: SCHNEIDER, T. Manual de dogmática. Vol. 1.2 ed. Petrópolis: Vozes, 2002, p. 389-390.

KITAMORI, K. Teologia del dolor de dios. Salamanca: Sigueme, 1975.

KUZMA, C. A. A esperança cristã na "teologia da esperança". 45 anos da teologia da esperança de Jürgen Moltmann: sua história, seu caminho, sua esperança. Revista Pistis Praxis, Curitiba, v. 1, n. 2, p. 443-467, jul./dez. 2009.

MOLTMANN, J. A fonte da vida: o Espírito Santo e a teologia da vida. São Paulo: Loyola, 2002.

MOLTMANN, J. Experiências de reflexão teológica: caminhos e formas da teologia cristã. São Leopoldo, RS: UNISINOS, 2004.

MOLTMANN, J. O caminho de Jesus Cristo: cristologia em dimensões messiânicas. Petrópolis: Vozes, 1993.

MOLTMANN, J. O Deus crucificado: a cruz de Cristo como base e crítica da teologia cristã. Santo André, SP: Academia Cristã, 2011.

MOLTMANN, J. Teologia da esperança: estudos sobre os fundamentos e as consequências de uma escatologia cristã. São Paulo: Loyola, 2005.

MOLTMANN, J. Trindade e Reino de Deus: uma contribuição para a teologia. Petrópolis: Vozes, 2000.

MOLTMANN, J. Vida, esperança e justiça: um testamento teológico para a América Latina. São Bernardo do Campo: Editeo, 2008.

MONDIN, B. Os grandes teólogos do século vinte. Santo André; São Paulo: Teológica; Paulus, 2003.

PANNENBERG, W. Teologia sistemática, v. 3. Santo André, SP: Academia cristã, 2009.

ROCHA, Z. J. B; MACIEL, K. D. S. A. Dois discursos de Freud sobre a religião. Revista Mal-estar e Subjetividade, Fortaleza, v. 8, n. 3, p. 729-754, set. 2008.

TORRES, A. Q. Repensar a revelação: a revelação de Deus na realização humana. São Paulo: Paulus, 1995.

RATZINGER, J. Introdução ao cristianismo. São Paulo: Loyola, 2005.

SCHILLEBEECKX, E. Jesus: a história de um vivente. São Paulo: Paulus, 2007.

Submetido em: 24-2-2018

Aceito em:28-6-2018 